\title{
INTERCOMPARISON OF OZONE AND TEMPERATURE PROFILES DURING OZITOS+ 2014 CAMPAIGN IN RÍO GALLEGOS, ARGENTINA
}

\author{
Jacobo Salvador ${ }^{1,2 *}$, Elian Wolfram ${ }^{1}$, Facundo Orte ${ }^{1}$, Raúl D'Elia ${ }^{1}$, Jonathan Quiroga ${ }^{1}$, Eduardo \\ Quel $^{1}$, Felix Zamorano ${ }^{3}$, Raúl Pérez ${ }^{3}$, Israel Villa ${ }^{3}$, Hirofumi Oyama ${ }^{4}$, Akira Mizuno ${ }^{4}$. \\ ${ }^{I}$ Centro de Investigaciones en Láseres y Aplicaciones, CEILAP-UNIDEF (MINDEF-CONICET), UMI- \\ IFAECI-CNRS-3351,UMI3351, Villa Martelli,Argentina, *Email: jacosalvador@gmail.com \\ ${ }^{2}$ Universidad Nacional de la Patagonia Austral, UNPA-UARG, Sta Cruz, Argentina \\ ${ }^{3}$ LICA Atmospheric Research Laboratory of Magallanes University, Punta Arenas Chile \\ ${ }^{4}$ ISEE Institute for Space-Earth Environmental Research, Nagoya University, Japan.
}

\begin{abstract}
In the framework of SAVER-Net project, the OZone profIle aT Río GallegOS (OZITOS+) campaign was held in the city of Río Gallegos, Argentina (51.5 S; 69.1 W). This experiment was conducted on October $14-18,2014$ and its main goal was to compare the ozone and temperature profiles using three different measurement techniques such as Differential Absorption Lidar (DIAL), ozonesonde and Millimeter Wave Radiometer (MWR). Also other ground-based and satellite-based instruments were included in the experiment but in this work we only present preliminary results from ground-based instruments deployed in the site. The DIAL instrument is part of Network Data for Atmospheric Composition Change (NDACC) network, and the usual protocols of quality assurance imposed for the network involve regular validation/comparisons experiments. The lidar ozone profiles measured with the lidar are compared with ozone profiles obtained with independent techniques, usually with higher or same resolution as lidar. The experiment are made collocated spatial and temporally. For that reason the Chilean team joined to Japanese and Argentine team at Río Gallegos to develop the experiment.

On October 2014, the Río Gallegos Observatory station was inside the polar vortex during first two weeks and after that polar vortex have moved far away from Río Gallegos during the 3rd week of October, when the intercomparison campaign was held.

In this paper we are present a preliminary results of the campaign, computing the ozone and
\end{abstract}

temperature profiles from DIAL with ozonesondes and MWR.

\section{INTRODUCTION}

The assessments of change induced by human activities on Earth atmosphere composition and thus on global climate requires a long term and regular survey of the troposphere and stratosphere layers.

In that frame, in 1990, the International Network for the Detection of Stratospheric Change (NDSC, http://www.ndsc.ncep.noaa.gov) was formed to provide a consistent, standardized set of long-term measurements of stratospheric trace gases, particles, and physical parameters via a suite of globally distributed sites. Within the NDSC, which was expanded and renamed Network for the Detection of Atmospheric Composition Change (NDACC) in 2006, lidar (laser radars) are key instruments for measuring the stratospheric ozone and temperature profile. Lidar measurements of ozone and temperature are selfcalibrating [1,2]. This makes them especially suited for long-term monitoring.

The Atmospheric Observatory of Southern Patagonia (OAPA) at Río Gallegos Argentina $(51.5 \mathrm{~S} ; 69.1 \mathrm{~W})$ is an extension of Laser and Application Research Department (CEILAP) in Buenos Aires. Since June 2005, a shelter with a differential absorption lidar developed in collaboration with Service d'Aéronomie (CNRS) was deployed in this Patagonian city, $2600 \mathrm{~km}$ far away Buenos Aires. This instrument was endorsed to NDACC in December 2008 and since this date several intercomparison campaigns were held as validation/control performance of the DIAL instrument. 
During 2005 and 2007, with the financial support of JICA (Japanese International Cooperation Agency), was held the SOLAR campaign (www.division-lidar.com.ar). The principal objective of this campaign was study the ozone layer when the polar vortex crosses over the continental part of Argentina, in South America. Río Gallegos is located in the surf zone of polar vortex, making very interesting place to observe the evolution and perturbation that ozone hole produces on the stratospheric ozone profile.

In the framework of the Project "Development of Atmospheric Environmental Risk Management System in South America", (SAVER-Net, 20132017) financed by JICA-JST through Science and Technology Research Partnership for Sustainable Development (SATREPS) was held the OZITOS+ campaign during October 2014.

In this work the preliminary results of this experiment are presented. The paper is organized as follow: in Section 2 are described the different instruments involved in this campaign and the section 3 the results of comparisons are presented followed with a short conclusions.

\section{METHODOLOGY}

There are three instruments involved in this OZITOS+ campaign: the Differential Absorption Lidar (DIAL), the ozone sondes and a millimeterwave radiometer (MWR). All of them measure the vertical profile of ozone content. However, they have different vertical resolution and dynamic range, thus they are complementary measurements that permit to obtain a vertical ozone profile from ground base to mesosphere (around $80 \mathrm{~km}$ ).

In the following paragraph we present a brief description of these three instruments used during the OZITOS+ campaign:

\subsection{Ozone Balloon-borne}

A Lockheed Martin LMG6 ground system unit, LMS6 meteorological radiosonde and electrochemical concentration cell (ECC) ozonesondes from EN-SCI Corporation have been used with $1 \%$ solution of KI. The ozone sensor of the ECC ozonesonde is an iodine/iodide redox concentration cell composed of two platinum electrodes immersed in neutral buffered iodide solutions of different concentration in the anode and cathode chambers. An electric current is generated when air containing ozone is pumped into the cathode. Both ECC and LMS6 are carried aloft on balloons from the ground to the burst altitude of the ballon, normally near $28-30 \mathrm{~km}$.

The ozone sondes launched in OZITOS+ campaign were managed by the personal of Atmospheric Research Laboratory of Magallanes University, that is the Chilean counterpart of SAVER-Net project.

\subsection{Differential Absorption Lidar}

This instrument was developed at the CEILAP laboratory and is an improved version of the previous one. The DIAL technique requires two emitted wavelengths that in this instrument are generated by two laser emitter: an excimer $(\mathrm{XeCl})$ laser emitting at $308 \mathrm{~nm}$ with $30 \mathrm{~Hz}$ repetition rate, and maximum energy per pulse of $300 \mathrm{~mJ}$ is used for the wavelength absorbed by ozone. The reference wavelength corresponds to the third harmonic of Nd-YAG laser emission, at $355 \mathrm{~nm}$, $30 \mathrm{~Hz}$ repetition rate and $130 \mathrm{~mJ}$ maximum energy. The optical receiver of the DIAL instrument that collects the backscattered photons is made up of four Newtonian ( $\mathrm{f} / 2$ ) telescopes. Each of them has a $50 \mathrm{~cm}$ diameter with parabolic aluminized surfaces of $48 \mathrm{~cm}$ diameter. A typical experiment lasts 3-4 h, leading to a horizontal spatial resolution of 100-200 $\mathrm{km}$. The measurements are taken during the night and with clear skies. The vertical resolution ranges from $0.7 \mathrm{~km}$ at $14 \mathrm{~km}$ to $4 \mathrm{~km}$ at $35 \mathrm{~km}$, with a corresponding total uncertainty varying from 3 to $15 \%$ in the same altitude range. This instrument contributes to NDACC and is one of only five instruments of this type in the Southern Hemisphere. The instrument is inside a shelter that was deployed inside an area of the Air Force Military Base of Río Gallegos in 2005, where today is emplaced the Observatorio Atmosférico de la Patagonia Austral (OAPA). The full description of DIAL instrument can be found in reference [3].

\subsection{Millimeter Wave Radiometer}

The MWR was developed and belongs to ISEE group from Nagoya University, Japan. In the millimeter measurements, molecular emission lines due to thermally excited rotational transitions at $110.836 \mathrm{GHz}$ are observed. We can measure the emission spectra day and night 
continuously because this method does not require any background light sources unlike absorption and scattering measurements. This is a great advantage. Such continuous measurements provide us valuable information on variations of the vertical distributions of ozone in the middle atmosphere with various timescale. In addition, the millimeter wave radiation is not affected by aerosols. Therefore, the vertical profile of ozone mixing ratio can be calculated exactly from the equations of radiative transfer at the millimeter wavelength. Typical altitudinal coverage and resolution are $\sim 20-80 \mathrm{~km}$ and $\sim 10-20 \mathrm{~km}$, respectively.

\section{EXPERIMENT AND RESULTS}

The OZITOS+ campaign was held during October 14 - 17, 2014 (Julian Day 287 to 291) in the Río Gallegos, Argentina. A total of six Electrochemical Chamber Cell (ECC) ozone sonde were launched during this campaign. In general the launch time was near midnight local time (3:00 UTC) and a second sounding after $3 \mathrm{hs}$ of departure time of the first one. The lidar measurement always needs clear skies conditions to get successful measurement output and for this reason this instrument is very weather dependent. During the week of the experiment, two main windows of clear skies were used, on the night of October 15 and the night of October 18.

Table I: Schedule of the observation days of the DIAL. Measurements coincident with the ozonesonde.

\begin{tabular}{cccc}
\hline $\begin{array}{c}\text { Day of } \\
\text { Oct, 2014 }\end{array}$ & $\begin{array}{c}\text { Start } \\
\text { Time } \\
\text { UTC }\end{array}$ & $\begin{array}{c}\text { End Time } \\
\text { UTC }\end{array}$ & $\begin{array}{c}\text { Integral } \\
\text { Time }\end{array}$ \\
\hline $\mathbf{1 5}$ & $00: 33: 00$ & $03: 12: 51$ & $148 \mathrm{~min}$ \\
\hline $\mathbf{1 5}$ & $03: 13: 52$ & $05: 43: 50$ & $148 \mathrm{~min}$ \\
\hline $\mathbf{1 5}$ & $05: 44: 51$ & $08: 16: 10$ & $150 \mathrm{~min}$ \\
\hline $\mathbf{1 6}$ & $05: 31: 30$ & $07: 34: 58$ & $116 \mathrm{~min}$ \\
\hline $\mathbf{1 6}$ & No obs. & No obs. & No obs. \\
\hline $\mathbf{1 8}$ & $00: 10: 15$ & $02: 47: 36$ & $148 \mathrm{~min}$ \\
\hline $\mathbf{1 8}$ & $02: 48: 37$ & $05: 18: 35$ & $148 \mathrm{~min}$ \\
\hline $\mathbf{1 8}$ & $05: 19: 37$ & $7: 48: 59$ & $148 \mathrm{~min}$ \\
\hline
\end{tabular}

Ozonesondes used during the campaign are small, lightweight, balloon-borne instruments capable of making measurements from the surface to near 35 $\mathrm{km}$ in altitude. In the Table I, we shown a schedule of the observation days of the DIAL measurements correlated with the ozonesonde flights.

In figure 1 we represents the total ozone column around the period of the campaign at Río Gallegos represented as vertical dashed line.

Total Ozone Río Gallegos 2014

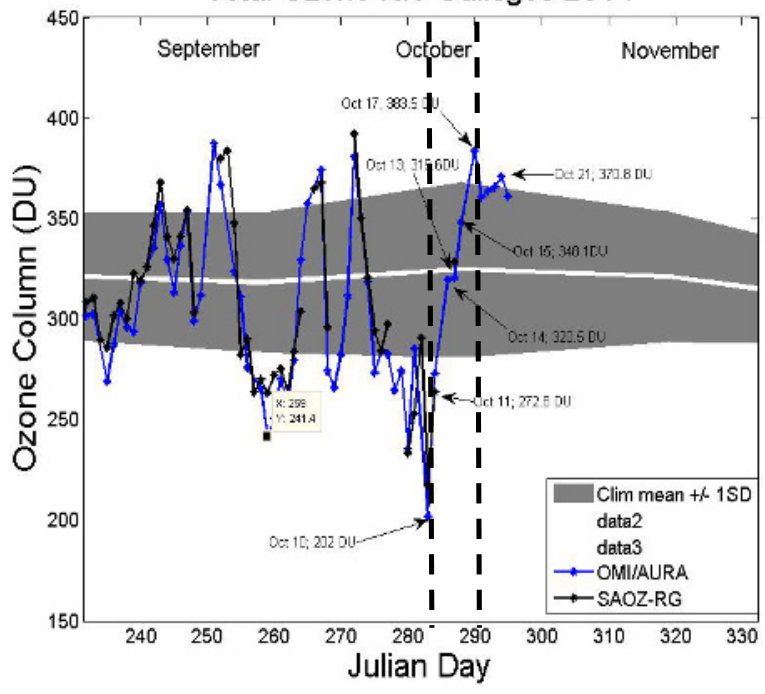

Figure 1. Total ozone column for Río Gallegos from OMI/AURA instrument and SAOZ instrument. White line is the climatological ozone mean (1978-2013) +/- 1SD (shadow gray zone). We show OMI/AURA and SAOZ data at Río Gallegos Station.

We have included in the representation the total ozone column provided by OMI/AURA and ground-based SAOZ instrument installed in the OAPA station. Both measurements are contrasted with the climatological data obtained from the Multi Sensor Reanalysis (MRS) database in the period 1978 to 2013 (white line) and its corresponding standard deviation (shadow gray zone) [4].

Figure 2 shows the ozone profile measured by the three techniques (DIAL-Balloon-borne-MWR) between October 15-18, 2014. Plots are represented in ozone number density. Shadow rows from Table I. are the days compared in the figure below. 


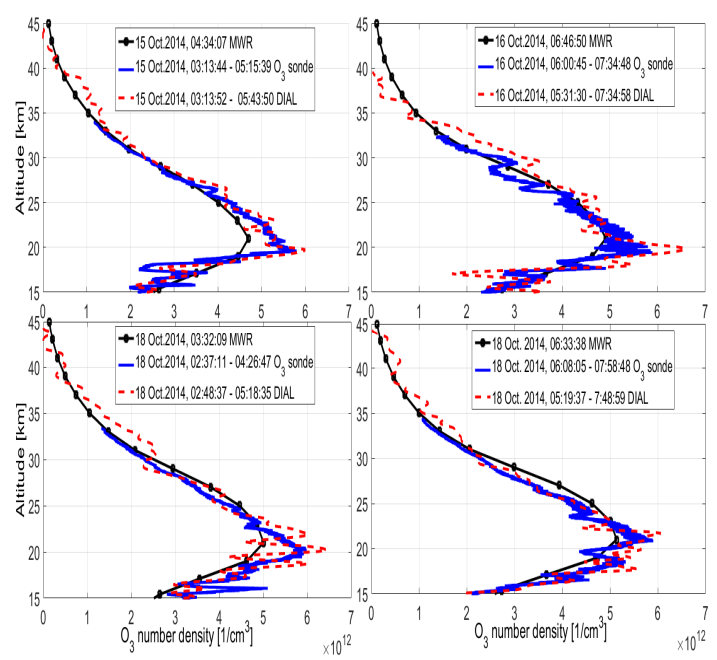

Figure 2. Example of comparisons with multi-instruments observing ozone profiles measured by DIAL (dashed line), ozonesonde (continuous line) and MWR (square line) on Oct 15-18, 2014.

The four measurements above shows good agreement between $\sim 20$ and $30 \mathrm{~km}$.

Figure 3 represents the temperature profiles computed from DIAL system during the campaign period, one profile per day since Oct. 14 to 18, compared with NCEP reanalysis at Río Gallegos.

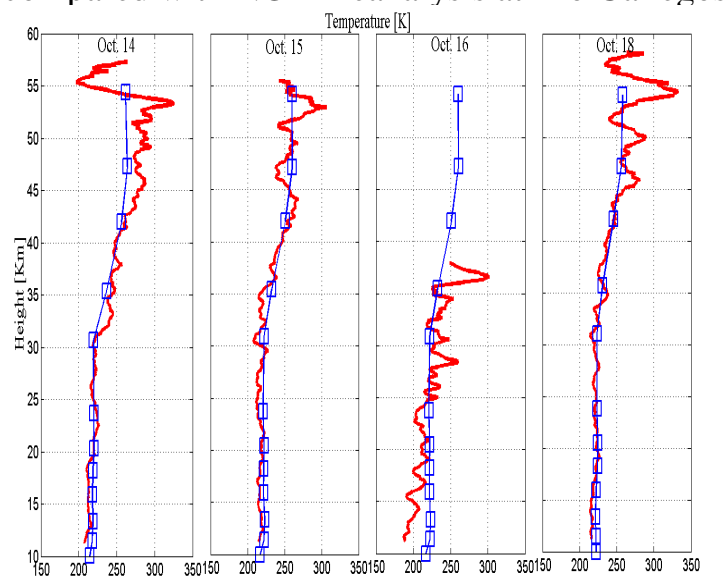

Figure 3. Evolution temperature profiles derived from Rayleigh Lidar (continuous line) and compared with Data reanalysis NCEP (square line) for Río Gallegos during the campaign days Oct 14-18 2014.

Applying signal processing over the Rayleigh lidar signals we can obtain the temperature profiles [5]. As the measurements obtained by DIAL system are longer than two hours integration time (IT) we have computed the temperature profile using an IT around $60 \mathrm{~min}$. coincident at middle period of time of flight of the ozone sounding

\section{CONCLUSIONS}

This first joined activity between Argentina, Chile and Japan for the ozone observation profiles at Patagonia in the framework of SAVER-Net project has been very successful from scientific and social point of view, given the opportunity to researchers of three countries to share their experiences and work together for a common goal. The preliminary analysis of the results obtained in this activity shows good agreement between different instruments and puts in evidence the high quality observation capability that SAVER-Net project produce for the monitoring of ozone hole and related issues associated with this.

\section{ACKNOWLEDGEMENT}

We would like to make special thanks to the Project "Development of Atmospheric Environmental Risk Management System in South America" (2013-2017) financed by JICAJST through Science and Technology Research Partnership for Sustainable Development (SATREPS). Also we would like to thank a SAOZ Network and FAA (Fuerza Aérea Argentina) for allowing us to use the Antarctic Storehouse during the campaign.

\section{REFERENCES}

1. Hauchecorne, A. and Chanin, M.-L.: Density and temperature profiles obtained by lidar between 35 and 70 km, Geophys. Res. Lett., 7, 565-568, 1980.

2. Megie, G. J., Ancellet, G., and Pelon, J.: Lidar measurements of ozone vertical profiles, Appl. Opt., 24, 3454-3463, 1985.

3. Wolfram E.A., J Salvador, R D'Elia, C Casiccia, N Paes Leme, A Pazmiño, J Porteneuve, S GodinBeekman, H Nakane and E J Quel. New differential absorption lidar for stratospheric ozone monitoring in Patagonia, South Argentina J. Opt. A: Pure Appl. Opt. 10 (2008) $104021 \quad$ (7pp). doi:10.1088/1464$4258 / 10 / 10 / 104021$.

4. Van der A, R. J., M. A. F. Allaart, and H. J. Eskes (2010), Multi sensor reanalysis of total ozone, Atmos. Chem. Phys. Discuss., 10, 11,401-11,448, doi:10.5194/acpd-10-11401-2010

5. Jacobo O. Salvador, Elian Wolfram, Raul D'Elia, Eduardo Quel, Temperature lidar retrieval using a Rayleigh lidar in Río Gallegos, Argentina. Óptica Pura y Aplicada 44 (2) 367-372 (2011). 